\title{
FLUVIRUCINS $\mathrm{A}_{1}, \mathrm{~A}_{2}, \mathrm{~B}_{1}, \mathrm{~B}_{2}, \mathrm{~B}_{3}, \mathrm{~B}_{4}$ AND $\mathrm{B}_{5}$, NEW ANTIBIOTICS ACTIVE AGAINST INFLUENZA A VIRUS
}

\section{TAXONOMY ON THE PRODUCING ORGANISMS}

\author{
Koji Tomita, Nahomi Oda, Yutaka Hoshino, \\ Noriyuki OHKusa and Hirotaka ChiKazawa ${ }^{\dagger}$ \\ Bristol-Myers Squibb Research Institute, \\ 2-9-3 Shimo-meguro, Meguro-ku, Tokyo 153, Japan
}

(Received for publication March 27, 1991)

\begin{abstract}
The morphology, chemotaxonomy, and cultural and physiological characteristics were examined on the five strains of actinomycetes which produce antiviral antibiotics, fluvirucin congeners. All strains have meso-2,6-diaminopimelic acid in the cell wall. Four strains, Q464-31, L407-5, R359-5 and R516-16, belong to the maduromycetes since they have madurose in the whole cell. The remaining one strain, R869-90, has rhamnose but no madurose, and is a nocardioform actinomycete. These five strains were classified and designated as follows:

Strain Q464-31 (fluvirucin $\mathrm{A}_{1}$ producer): Microtetraspora tyrrhenii sp. nov. (Actinomadura pusilla group).

Strain L407-5 (fluvirucin $B_{2}$ producer): A maduromycete.

Strain R359-5 (fluvirucin $\mathrm{B}_{1}$ producer): Microtetraspora pusilla (Actinomadura pusilla group).

Strain R869-90 (fluvirucin $A_{2}$ producer): Saccharothrix mutabilis.

Strain R516-16 (fluvirucins $\mathrm{B}_{2}, \mathrm{~B}_{3}, \mathrm{~B}_{4}$ and $\mathrm{B}_{5}$ producer): $\mathrm{A}$ maduromycete.
\end{abstract}

In the course of searching for new antiviral antibiotics from the fermentation broth of soil microorganisms, five unusual actinomycetes were found to produce a family of antibiotics consisted of seven components, designated fluvirucins $A_{1}, A_{2}, B_{1}, B_{2}, B_{3}, B_{4}$ and $B_{5}$. The production, biological and chemical properties and structure of fluvirucins were described in the preceding papers ${ }^{1 \sim 3)}$.

This paper describes the characterization and taxonomic position of these five unusual actinomycete strains.

\section{Materials and Methods}

The cultural and physiological characteristics of the five strains were examined by the methods of ShIRLING and GotTlies ${ }^{4)}$, and GoRdon et al. ${ }^{5}$. Diagnostic components of amino acid and sugar in the whole cell hydrolysate were analyzed by the methods of LECHEVALIER ${ }^{6)}$. The phospholipids were identified by the methods of LECHEVALIER et al. ${ }^{7}$. The menaquinone samples were prepared by the procedures of Collins $e t$ al. ${ }^{8)}$ and analyzed with a mass spectrometer. The glycolate test and the detection of mycolate were carried out by the methods of UCHIDA and AIDA ${ }^{9)}$, and MINNIKIN et al ${ }^{10)}$, respectively. The composition of methyl esterified cellular fatty acids was analyzed by GC with SPB-1 fused silica capillary column $(0.25 \mathrm{~mm} \times 30 \mathrm{~m})$, and determined by GC-MS.

\section{Results}

The morphology, cell chemistry, fatty acid composition, and cultural and physiological characteristics

\footnotetext{
+ Preclinical Research Laboratories, 1 Futagoyama, Sakazaki, Kohda-cho, Nukata-gun, Aichi Prefecture 600, Japan.
} 
of the five strains are shown in Tables $1,2,3,4$ and 5, respectively.

The supplemental characteristics and their taxonomic position are described below.

Table 1. Morphology of five strains of actinomycetes.

\begin{tabular}{|c|c|c|c|c|c|}
\hline & Strain Q464-31 & Strain L407-5 & Strain R359-5 & Strain R869-90 & Strain R516-16 \\
\hline \multicolumn{6}{|l|}{ Aerial mycelium: } \\
\hline Formation & $\begin{array}{l}\text { Moderate } \\
\text { (ISP No. 3) }\end{array}$ & None & $\begin{array}{l}\text { Abundant } \\
\text { (ISP No. 2) }\end{array}$ & $\begin{array}{l}\text { None or sparse } \\
\text { (ISP Nos. } 2 \\
5,7 \text { ) }\end{array}$ & None \\
\hline Spore chain & $\begin{array}{l}\text { Short; hook } \\
\text { or spiral } \\
\quad(5 \sim 15 \text { spores })\end{array}$ & None & $\begin{array}{l}\text { Short; hook } \\
\text { or spiral } \\
\quad(10 \sim 30 \text { spores })\end{array}$ & $\begin{array}{l}\text { Long straight } \\
\text { chains of } \\
\text { spores of } \\
\text { various lengths }\end{array}$ & None \\
\hline Spores & $\begin{array}{l}\text { Oval }(1.2 \times \\
1.6 \sim 2.5 \mu \mathrm{m}) \\
\text { surface with } \\
\text { vertical ridges }\end{array}$ & None & $\begin{array}{l}\text { Oval }(0.8 \times \\
1.0 \times 2.0 \mu \mathrm{m}) \\
\text { smooth surface }\end{array}$ & $\begin{array}{l}\text { Rod }(0.6 \times \\
\quad 0.8 \sim 3.0 \mu \mathrm{m}) \\
\text { smooth surface }\end{array}$ & None \\
\hline $\begin{array}{l}\text { Special } \\
\text { morphology }\end{array}$ & None & None & $\begin{array}{l}\text { Pseudosporang- } \\
\text { ium (coiled } \\
\text { spore chain } \\
\text { with pseudo- } \\
\text { membrane) }\end{array}$ & $\begin{array}{l}\text { Fascicled thick } \\
\text { hyphae, and } \\
\text { sclerotic } \\
\text { granules }\end{array}$ & None \\
\hline \multicolumn{6}{|l|}{ Substrate mycelium: } \\
\hline Fragmentation & None & None & None & $\begin{array}{l}\text { Occurred } \\
\text { (various } \\
\text { lengths) }\end{array}$ & None \\
\hline $\begin{array}{l}\text { Special } \\
\text { morphology }\end{array}$ & None & $\begin{array}{l}\text { Dichotomously } \\
\text { and repeatedly } \\
\text { branched curled } \\
\text { hyphae }\end{array}$ & None & None & $\begin{array}{l}\text { Dichotomously } \\
\text { and repeatedly } \\
\text { branched curled } \\
\text { hyphae }\end{array}$ \\
\hline
\end{tabular}

Table 2. Cell chemistry of five strains of actinomycetes.

\begin{tabular}{|c|c|c|c|c|c|}
\hline & Strain Q464-31 & Strain L $407-5$ & Strain R359-5 & Strain R869-90 & Strain R516-16 \\
\hline \multicolumn{6}{|c|}{ Whole cell hydrolysate: } \\
\hline $\begin{array}{l}\text { Diaminopimelic } \\
\text { acid }\end{array}$ & meso & meso & meso & meso & meso \\
\hline Sugar & $\begin{array}{l}\text { Glucose, } \\
\text { madurose }\end{array}$ & $\begin{array}{l}\text { Galactose, } \\
\text { glucose, } \\
\text { mannose, } \\
\text { madurose, } \\
\text { ribose }\end{array}$ & $\begin{array}{l}\text { Glucose, } \\
\text { mannose, } \\
\text { madurose, } \\
\text { ribose }\end{array}$ & $\begin{array}{l}\text { Galactose, } \\
\text { glucose, } \\
\text { mannose, } \\
\text { ribose, } \\
\text { rhamnose }\end{array}$ & $\begin{array}{l}\text { Glucose, } \\
\text { mannose } \\
\text { madurose, } \\
\text { ribose }\end{array}$ \\
\hline Cell wall type & $\mathrm{III}_{\mathrm{B}}$ & $\mathrm{III}_{\mathbf{B}}$ & $\mathrm{III}_{\mathrm{B}}$ & $\mathrm{III}_{\mathrm{C}}$ & $\mathrm{III}_{\mathrm{B}}$ \\
\hline Phospholipids $^{\mathrm{a}}$ & $\begin{array}{l}\text { PIM, GluNU, } \\
\text { PI, PE, OPE, } \\
\text { DPG }\end{array}$ & $\begin{array}{l}\text { PIM, GluNU, } \\
\text { PI, PE, DPG }\end{array}$ & $\begin{array}{l}\text { PIM, GluNU, } \\
\text { PI, PE, OPE, } \\
\text { DPG }\end{array}$ & $\begin{array}{l}\text { PI, GluNU, PE, } \\
\text { OPE }\end{array}$ & $\begin{array}{l}\text { PI, PG, GluNU, } \\
\text { DPG }\end{array}$ \\
\hline Type & P-IV & P-IV & P-IV & P-IV & P.V (tentative) \\
\hline $\begin{array}{l}\text { Major } \\
\text { menaquinone }\end{array}$ & MK-9 $\left(\mathrm{H}_{4}\right)$ & MK-9 $\left(\mathrm{H}_{4}\right)$ & $\mathrm{MK}-9\left(\mathrm{H}_{4}\right)$ & MK-9 $\left(\mathrm{H}_{4}\right)$ & MK-9 $\left(\mathrm{H}_{4}\right)$ \\
\hline Mycolate & Absent & Absent & Absent & Absent & Absent \\
\hline Fatty acid pattern ${ }^{b}$ & $3 \mathrm{c}$ & $3 \mathrm{c}$ & $3 c$ & $3 \mathrm{f}$ & $3 \mathrm{c}$ \\
\hline Glycolate test & Negative & Negative & Negative & Negative & Negative \\
\hline
\end{tabular}

a Abbreviations: PIM, Phosphatidylinositol mannoside; GluNU, unknown glucosamine-containing phospholipids; PI, phosphatidylinositol; PE, phosphatidylethanolamine; OPE, hydroxylated phosphatidylethanolamine; DGP, diphosphatidylglycerol; PG, phosphatidylglycerol.

b According to the classification of GRUND and KROPPENSTEDT ${ }^{16}$. 
Table 3. Fatty acid composition of five strains of actinomycetes.

\begin{tabular}{|c|c|c|c|c|c|c|c|c|c|c|c|c|c|c|c|c|}
\hline \multirow{3}{*}{ Strain No. } & \multicolumn{16}{|c|}{ Fatty acid composition (\%) } \\
\hline & \multicolumn{3}{|c|}{ Straight chain } & \multicolumn{4}{|c|}{ Branched chain } & \multicolumn{5}{|c|}{ Unsaturated } & \multicolumn{3}{|c|}{ 10-Methyl branched chain } & \multirow{2}{*}{$\begin{array}{l}\text { Hydroxylated } \\
\text { fatty acids }\end{array}$} \\
\hline & $15: 0$ & $16: 0$ & $17: 0$ & $i-15$ & $i-16$ & $a-15$ & $a-17$ & $i-16: 1$ & $\begin{array}{c}c i s 9 \\
16: 1\end{array}$ & $\begin{array}{c}c i s 9 \\
17: 1\end{array}$ & $i-18: 1$ & $\begin{array}{c}c i s 9 \\
18: 1\end{array}$ & $\begin{array}{c}10 \mathrm{Me} \\
16: 0\end{array}$ & $\begin{array}{c}10 \mathrm{Me} \\
17: 0\end{array}$ & $\begin{array}{c}10 \mathrm{Me} \\
18: 0\end{array}$ & \\
\hline Q464-31 & 4 & 6 & 6 & 2 & 19 & & & 8 & 4 & 7 & 3 & 2 & 3 & 16 & 3 & 8 \\
\hline L407-5 & 4 & 3 & 8 & 2 & 10 & & & 8 & 5 & 11 & 3 & 3 & 1 & 17 & 5 & 10 \\
\hline R359-5 & 3 & 2 & 2 & 2 & 23 & & & 19 & 3 & 7 & 4 & 2 & 3 & 11 & 2 & 10 \\
\hline $\mathrm{R} 869-90$ & & 5 & & 10 & 9 & 12 & 10 & & 15 & & & 1 & 11 & 2 & & 16 \\
\hline R516-16 & 3 & 4 & 5 & 2 & 17 & & & 11 & 5 & 6 & 5 & 2 & 2 & 11 & 4 & 12 \\
\hline
\end{tabular}

Abbreviations (examples): Straight chain saturated, 15:0, pentadecanoic acid; iso-branched chain, $i$ - 16,14 -methylpentadecanoic acid; anteiso-branched chain, $a$ - 17 14-methylhexadecanoic acid; monounsaturated straight chain, cis $9-18: 1,9$-octadecenoic acid (oleic acid); 10-methylbranched chain, 10Me 18:0, 10-methyloctadecanoic acid (tuberculostearic acid); hydroxylated fatty acids, 2-hydroxy-14-methylpentadecanoic acid, 2-hydroxy-hexadecenoic acid, etc. 
Table 4. Cultural characteristics of five strains of actinomycetes.

\begin{tabular}{|c|c|c|c|c|c|c|}
\hline & & Strain Q464-31 & Strain L407-5 & Strain R359-5 & Strain R869-90 & Strain R516-16 \\
\hline \multirow[t]{3}{*}{$\begin{array}{l}\text { Yeast extract - malt extract agar } \\
\text { (ISP No. 2) }\end{array}$} & G: & $\begin{array}{l}\text { Good; deep yellowish } \\
\text { brown (75) }\end{array}$ & Good; deep brown (56) & $\begin{array}{l}\text { Good; strong brown } \\
\text { (55) }\end{array}$ & $\begin{array}{l}\text { Good; moderate } \\
\quad \text { orange yellow }(71)\end{array}$ & Good; deep brown (56) \\
\hline & A: & Poor; white & None & $\begin{array}{l}\text { Abundant; yellowish } \\
\text { white (92) }\end{array}$ & Very scant; white & None \\
\hline & $\mathrm{D}:$ & None & None & None & None & None \\
\hline \multirow[t]{3}{*}{ Oatmeal agar (ISP No. 3) } & G: & $\begin{array}{l}\text { Moderate; light yellow } \\
\text { (86) }\end{array}$ & Good; light yellow (92) & $\begin{array}{l}\text { Moderate; light brown } \\
(57)\end{array}$ & $\begin{array}{l}\text { Moderate; pale orange } \\
\text { yellow }(70)\end{array}$ & Good; strong yellow (84) \\
\hline & A: & Moderate; white & None & $\begin{array}{l}\text { Moderate; yellowish } \\
\text { white (92) }\end{array}$ & None & None \\
\hline & $\mathrm{D}:$ & None & None & Pale yellow $(89)$ & None & None \\
\hline \multirow[t]{3}{*}{$\begin{array}{l}\text { Inorganic salts - starch agar } \\
\text { (ISP No. 4) }\end{array}$} & G: & $\begin{array}{l}\text { Poor; light olive brown } \\
\text { (94) }\end{array}$ & $\begin{array}{l}\text { Poor; moderate yellow } \\
\quad(87)\end{array}$ & $\begin{array}{l}\text { Poor; moderate yellow } \\
\quad(87)\end{array}$ & $\begin{array}{l}\text { Moderate; light olive } \\
\text { brown (94) }\end{array}$ & Poor; pale yellow (89) \\
\hline & A: & Scant; white & None & None & None & None \\
\hline & D: & None & None & None & None & None \\
\hline \multirow[t]{3}{*}{$\begin{array}{l}\text { Glycerol - asparagine agar } \\
\text { (ISP No. 5) }\end{array}$} & $\mathrm{G}:$ & $\begin{array}{l}\text { Moderate; dark yellow } \\
\text { (88) }\end{array}$ & $\begin{array}{l}\text { Poor; moderate yellow } \\
\quad(87)\end{array}$ & $\begin{array}{l}\text { Scant; moderate yellow } \\
\text { (87) }\end{array}$ & $\begin{array}{l}\text { Moderate; deep yellow } \\
(88)\end{array}$ & Poor; pale yellow (89) \\
\hline & A: & None & None & None & Very scant; white & None \\
\hline & D: & None & None & None & None & None \\
\hline \multirow[t]{3}{*}{$\begin{array}{l}\text { Peptone - yeast extract - iron } \\
\text { agar (ISP No. 6) }\end{array}$} & G: & $\begin{array}{l}\text { Moderate; deep } \\
\text { yellowish brown (75) }\end{array}$ & $\begin{array}{l}\text { Moderate; deep } \\
\text { yellowish brown (75) }\end{array}$ & $\begin{array}{l}\text { Moderate; light } \\
\text { yellowish brown (76) }\end{array}$ & Good; colorless & $\begin{array}{l}\text { Moderate; deep } \\
\text { yellowish brown }(75)\end{array}$ \\
\hline & A: & None & None & None & None & None \\
\hline & $\mathrm{D}:$ & None & None & None & None & None \\
\hline \multirow[t]{3}{*}{ Tyrosine agar (ISP No. 7) } & G: & $\begin{array}{l}\text { Moderate; dark yellow } \\
\text { (88) }\end{array}$ & $\begin{array}{l}\text { Poor; grayish brown } \\
\quad(61)\end{array}$ & Scant; pale yellow (89) & $\begin{array}{l}\text { Good; dark orange } \\
\text { yellow (72) }\end{array}$ & $\begin{array}{l}\text { Poor; grayish yellow } \\
\quad(90)\end{array}$ \\
\hline & A: & None & None & None & $\begin{array}{l}\text { Poor; yellowish white } \\
\text { (92) }\end{array}$ & None \\
\hline & $\mathrm{D}$ : & None & None & None & None & None \\
\hline
\end{tabular}

Observation after incubation at $28^{\circ} \mathrm{C}$ for 3 weeks.

Color name used: ISCC-NBS Color-name Charts.

Abbreviations: G, Growth and reverse color; A, aerial mycelium; D, diffusible pigment. 
Table 5. Physiological characteristics of five strains of actinomycetes.

\begin{tabular}{|c|c|c|c|c|c|}
\hline Strain & Q464-31 & L $407-5$ & R359-5 & $\mathrm{R} 869-90$ & R516-16 \\
\hline \multicolumn{6}{|l|}{ Decomposition of: } \\
\hline Adenine & + & - & - & - & - \\
\hline Casein & + & + & + & + & + \\
\hline Hippuric acid & + & + & + & + & + \\
\hline Hypoxanthine & + & + & + & + & + \\
\hline Tyrosine & + & - & - & + & - \\
\hline Xanthine & - & - & - & - & - \\
\hline \multicolumn{6}{|l|}{ Decarboxylation of: } \\
\hline Benzoate & - & - & - & - & - \\
\hline Citrate & + & - & + & + & - \\
\hline Mucate & - & - & - & - & - \\
\hline Succinate & + & + & + & + & + \\
\hline Tartrate & - & + & - & - & $+w$ \\
\hline \multicolumn{6}{|l|}{ Production of: } \\
\hline Amylase & + & + & + & + & + \\
\hline Esculinase & + & + & + & + & + \\
\hline Gelatinase & - & + & + & + & + \\
\hline Nitrate reductase ${ }^{a}$ & $-1+$ & $-1+$ & $+1+$ & $+1-$ & $+1+$ \\
\hline Tyrosinase & - & - & - & - & - \\
\hline Urease & + & $+w$ & - & - & $+w$ \\
\hline \multicolumn{6}{|l|}{ Growth in/at: } \\
\hline Lysozyme, $0.01 \%$ & - & - & - & + & - \\
\hline $\mathrm{NaCl}, 3 \%$ & + & + & + & + & + \\
\hline $5 \%$ & - & - & - & + & - \\
\hline Temperature, $43^{\circ} \mathrm{C}$ & - & + & - & + & + \\
\hline $46^{\circ} \mathrm{C}$ & - & + & - & - & - \\
\hline \multicolumn{6}{|c|}{ Carbohydrate utilization: ${ }^{b}$} \\
\hline Adonitol & + & + & + & $+w$ & + \\
\hline D-Arabinose & + & + & + & + & + \\
\hline L-Arabinose & + & + & + & + & + \\
\hline Cellobiose & + & + & + & + & + \\
\hline Dulcitol & - & - & - & - & - \\
\hline Erythritol & - & + & - & - & - \\
\hline D-Fructose & + & + & + & + & + \\
\hline D-Galactose & + & - & + & + & + \\
\hline D-Glucose & + & + & + & + & + \\
\hline Glycerol & + & + & + & + & + \\
\hline Inositol & + & + & + & + & + \\
\hline Lactose & + & + & + & + & + \\
\hline D-Mannitol & + & + & + & + & + \\
\hline D-Mannose & + & + & + & + & + \\
\hline D-Melezitose & - & - & - & - & $+w$ \\
\hline Melibiose & + & + & + & + & + \\
\hline Methyl- $\alpha$-glucoside & $+w$ & + & + & $+w$ & + \\
\hline Raffinose & + & + & - & + & + \\
\hline L-Rhamnose & + & + & + & + & + \\
\hline D-Ribose & + & - & + & + & $+w$ \\
\hline Salicin & + & - & + & + & + \\
\hline D-Sorbitol & - & - & - & - & - \\
\hline D-Sorbose & - & - & - & - & - \\
\hline Sucrose & + & + & + & + & + \\
\hline Trehalose & + & + & + & + & + \\
\hline D-Xylose & + & + & + & + & + \\
\hline
\end{tabular}

a Sucrose - nitrate broth/peptone - nitrate broth.

b Basal medium: PridhaM-GotTlieB's inorganic salts medium (ISP No. 9). +w: Weakly positive. 


\section{Strain Q464-31 (Fluvirucin $A_{1}$ Producer)}

Hook or spiral spore-chains were formed monopodially on the tip of aerial hyphae. The spores were big and had vertical folds on the surface (Fig. 1). White aerial mycelium was formed on ISP media Nos. 2, 3 and 4. The colony on ISP medium No. 2 was rigid, convex or crateriform and brownish. Melanin and other distinct pigments were not produced. Growth occurred between $17^{\circ} \mathrm{C}$ and $40^{\circ} \mathrm{C}$, or in $\mathrm{NaCl}$ at $3 \%$ or less.

The morphology and cell chemistry of strain Q464-31 indicated that the strain should be placed in the Actinomadura pusilla group ${ }^{11)}$ which was proposed to be separated from the genus Actinomadura and reclassified in the genus Microtetraspora ${ }^{12)}$. Based on the direct or descriptive comparisons of the strain to the known species of the A. pusilla group ${ }^{13,14)}$, strain Q464-31 was differentiated from the known species by its spores with vertical ridges and some physiological characteristics including the decomposition of adenine, the presence of urease and the absence of gelatinase. Thus, strain Q464-31 is classified as a new species of the genus Microtetraspora. The proposed designation is Microtetraspora tyrrhenii sp. nov. (tyrrhenii, tyr-re'-ni-i, L. adj. referring to the Tyrrhenian Sea in Mediterranean Sea, which the soil source site of this organism faces). The type strain is No. Q464-31 (ATCC 53931), which is single isolate.

The source of strain Q464-31 was a soil sample collected in the river side of Tevere (Tiber) River, Rome, Italy.

\section{Strain L407-5 (Fluvirucin $B_{2}$ Producer)}

None of the aerial mycelium or spores was formed (Fig. 2). Formation of aerial mycelium was neither seen on the additional media such as starch-casein agar and soil extract agar and nor induced by the supplement of vitamin B complex to chemically defined ISP media or CZAPEK's sucrose - nitrate agar. The vegetative mycelium was non-fragmentary. The colony on ISP medium No. 2 was rigid, convex or crateriform and brownish. Melanin and other distinct pigments were not formed. Growth occurred between $20^{\circ} \mathrm{C}$ and $46^{\circ} \mathrm{C}$ or in $\mathrm{NaCl}$ at $4 \%$ or less.

The taxonomic position (genus) of strain L407-5 is unknown due to its non-sporulating property. Based on the chemotaxonomy of strain L407-5, the strain was designated tentatively as a maduromycete ${ }^{15}$.

The source of strain L407-5 was a soil sample collected in Madhya Pradesh State, India.

\section{Strain R359-5 (Fluvirucin $B_{1}$ Producer)}

Hook or spiral short spore-chains were formed monopodially on the tip of aerial hyphae. Some coiled

Fig. 1. Strain Q464-31.

A chain of spores with vertical folds (cultivation on ISP medium No. 2 for 3 weeks).

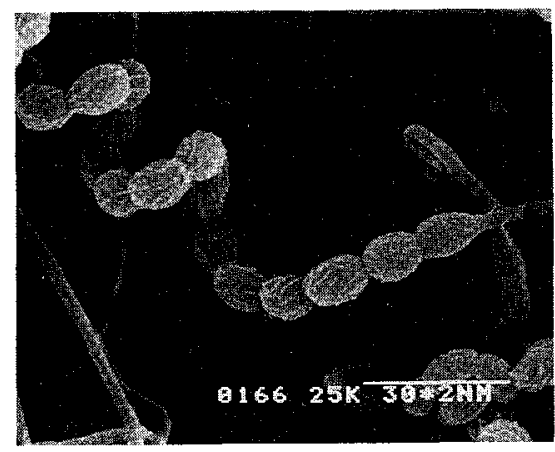

Fig. 2. Strain L407-5.

Non-sporogenic hyphae.

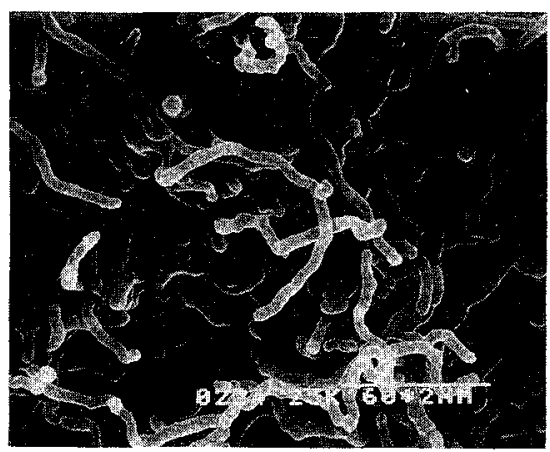


Fig. 3. Strain R359-5.

A chain of spores with smooth surface (cultivation on ISP medium No. 2 for 3 weeks).

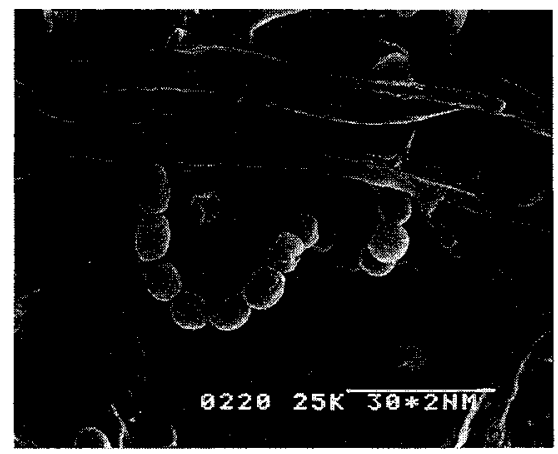

Fig. 4. Strain R359-5.

Pseudosporangia on the aerial mycelium (cultivation on ISP medium No. 2 for 3 weeks).

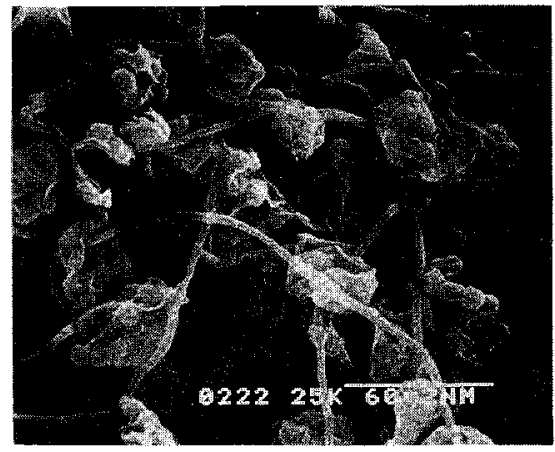

spore-chains were observed as a pseudosporangium with pseudomembrane by scanning electron microscopy. The spores were oval and had a smooth surface (Figs. 3 and 4). Aerial mycelium was formed only on ISP media Nos. 2 and 3, and the color of mycelium was white or yellowish white. On chemically defined media the growth was scant, and aerial mycelium was not formed. The substrate mycelium was non-fragmentary. The colony on ISP medium No. 2 was rigid, convex or crateriform and brownish. Melanin and other distinct pigments were not formed. Growth occurred between $20^{\circ} \mathrm{C}$ and $41^{\circ} \mathrm{C}$ or in $\mathrm{NaCl}$ at $3 \%$ or less.

The morphology and cell chemistry of strain R359-5 indicated that the strain is placed in the A.pusilla group $^{11}$ which was proposed to be reclassified in the genus Microtetraspora ${ }^{12)}$. Among the known species of the A. pusilla group, strain R359-5 shares many common characteristics with $A$. pusilla ${ }^{13.14)}$. The two organisms form the short spiral spore-chain pseudosporangium, the spores with smooth surface, the yellowish white aerial mycelium, the brownish substrate mycelium, and none of diffusible pigments. They show a similar sugar utilization profile. Strain R359-5 is differentiated from $A$. pusilla in its predominant formation of spiral spore-chains, limited formation of pseudosporangium, growth in $3 \%-\mathrm{NaCl}$, and hydrolysis of casein and starch. Since the differences between the two organisms are limited, strain R359-5 was identified as Microtetraspora pusilla (Nonomura and Ohara) KROPPENSTEDT et al. ${ }^{12)}$.

The source of strain R359-5 was a soil sample collected in La Carlota, Negros Island, Philippines.

\section{Strain R869-90 (Fluvirucin $A_{2}$ Producer)}

Aerial mycelium was sparsely formed on ISP media Nos. 2, 5 and 7. Long and straight chains of segments were born in the total parts of the aerial mycelium. These segments consisted of rods of varying lengths and had a smooth surface. Mature spores occurred discontinuously in the segmented hyphae (Fig. 5). Fascicled thick hyphae and sclerotic granules were formed on the aerial mycelium. Zigzag hyphae were not observed. The substrate mycelium was fragmentary. The colony on ISP medium No. 2 was soft, smooth, drop-like and colorless to yellowish. Melanin and other pigments were not formed. Growth occurred between $17^{\circ} \mathrm{C}$ and $44^{\circ} \mathrm{C}$ or in $\mathrm{NaCl}$ at $6 \%$ or less.

The morphology, cell chemistry, and cultural and physiological characteristics of strain R869-90 indicated that the strain is placed in Saccharothrix mutabilis, (Shearer, Colman and Nash III) GRUND and KROPPENSTEDT $^{16)}$, a nocardioform actinomycete ${ }^{17,18)}$, which was proposed to be reclassified from the genus Nocardiopsis ${ }^{16)}$.

The source of strain R869-90 was a soil sample collected in Maharashtra State, India. 
Fig. 5. Strain R869-90.

Segmented aerial hyphae with mature spores (cultivation on ISP medium No. 7 for 3 weeks).

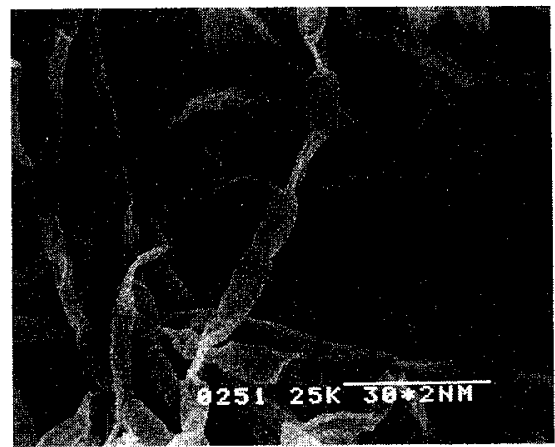

Fig. 6. Strain R516-16.

Non-sporogenic hyphae.

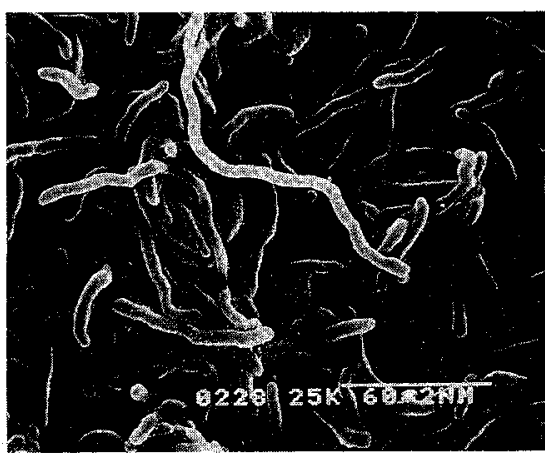

Strain R516-16 (Fluvirucins $\mathrm{B}_{2}, \mathrm{~B}_{3}, \mathrm{~B}_{4}$, and $\mathrm{B}_{5}$ Producer)

None of the aerial mycelium and spores was formed (Fig. 6). Formation of the aerial mycelium was neither seen in additional media such as starch-casein agar and soil extract agar, and nor induced by the supplement of vitamin B complex to chemically defined ISP media or CZAPEK's sucrose - nitrate agar. The vegetative mycelium was non-fragmentary. The colony on ISP medium No. 2 was rigid, convex or crateriform and brownish. Melanin and other distinct pigments were not formed. Growth occurred between $22^{\circ} \mathrm{C}$ and $43^{\circ} \mathrm{C}$ or in $\mathrm{NaCl}$ at $3 \%$ or less.

Like strain L407-5, strain R516-16 was a non-sporulating maduromycete. Strain R516-16 was similar to strain L407-5 in the cultural characteristics, but differed in the phospholipid pattern (its absence of phosphatidylethanolamine and the presence of phosphatidylglycerol). Physiologically, strain R516-16 was different from the latter in the absence of growth at $46^{\circ} \mathrm{C}$, utilization of D-galactose, and lack of utilization of erythritol.

Thus, strain R516-16 was designated tentatively as a maduromycete ${ }^{15}$, which has distinct diferences from another non-sporogenic maduromycete, strain L407-5. The source of strain R516-16 was a soil sample collected in Maharashtra State, India.

\section{Discussion}

The final taxonomic position of the two strains, L407-5 and R516-16, was not determined due to their absence of sporulation. The taxonomic relationships among the two-non-sporogenic strains, strain Q464-31 (M. tyrrhenii), strain R359-5 (M. pusilla) and the type strains of $M$. pusilla and related species are of interest, and will be followed up using additional chemotaxonomical and/or molecular genetic methods.

\section{Acknowledgments}

The authors are grateful to Dr. T. OKI, the director of their research institute, for his encouragement through this work, and to Dr. T. Tsuno and Miss M. BABA for the menaquinone analysis by mass spectrometry and the quantitative fatty acid analysis by gas chromatography.

\section{References}

1) Naruse, N.; O. Tenmyo, K. Kawano, K. Tomita, N. Ohgusa, T. Mryakı, M. Konishi \& T. Oki: Fluvirucins 
$A_{1}, A_{2}, B_{1}, B_{2}, B_{3}, B_{4}$ and $B_{5}$, new antibiotics active against influenza $A$ virus. I. Production, isolation, chemical properties and biological activities. J. Antibiotics 44: 733 740, 1991

2) Naruse, N.; T. Tsuno, Y. Sawada, M. Konishi \& T. Okr: Fluvirucins $A_{1}, A_{2}, B_{1}, B_{2}, B_{3}, B_{4}$ and $B_{5}$, new antibiotics active against influenza $A$ virus. II. Structure determination. J. Antibiotics 44: 741 755, 1991

3) Naruse, N.; M. Konishi, T. OKI, Y. Inouye \& H. Kakisawa: Fluvirucins $A_{1}, A_{2}, B_{1}, B_{2}, B_{3}, B_{4}$ and $B_{5}$, new antibiotics active against influenza $A$ virus. III. The stereochemistry and absolute configuration of fluvirucin $A_{1}$. J. Antibiotics 44: 756 761, 1991

4) Shirling, E. B. \& D. Gottlieb: Methods for characterization of Streptomyces species. Int. J. Syst. Bacteriol. 16: $313 \sim 340,1966$

5) Gordon, R. E; S. K. Mishra \& D. A. BarnetT: Some bits and pieces of the genus Nocardia: N. carnea, $N$. vaccinii, N. transvalensis, N. orientalis and N. aerocolonigenes. J. Gen. Miocrobiol. 109: 69 78, 1978

6) LECHEVALIER, M. P.: Identification of aerobic actinomycetes of clinical importance. J. Lab. Clin. Med. 71:934 944, 1968

7) Lechevalier, M. P.; C. D. Bievre \& H. Lechevalier: Chemotaxonomy of aerobic actinomycetes: Phospholipid composition. Biochem. Syst. Ecol. 5: $249 \sim 260,1977$

8) Collins, M. D.; T. Pirouz, M. Goodfellow \& D. E. Minnikin: Distribution of menaquinones in actinomycetes and corynebacteria. J. Gen. Microbiol. 100: $221 \sim 230,1977$

9) UCHIDA, K. \& K. AIDA: Taxonomic significance of cell-wall acyl type in Corynebacterium-Mycobacterium-Nocardia group by a glycolate test. J. Gen. Appl. Microbiol. 25: $169 \sim 183,1979$

10) Minnikin, D. E.; L. Alshamaony \& M. Goodfellow: Differentiation of Mycobacterium, Nocardia, and related taxa by thin-layer chromatographic analysis of whole-organism methanolysates. J. Gen. Microbiol. 88: 200 204, 1975

11) Goodfellow, M.; E. Stackebrandt \& R. M. Kroppenstedt: Chemotaxonomy and actinomycete systematics. In Biology of Actinomycetes '88. Ed., Y. OKAMI et al., pp. $233 \sim 238$, Japan Scientific Societies Press, 1988

12) Kroppenstedt, R. M.; E. Stackebrandt \& M. Goodfellow: Taxonomic revision of the actinomycete genera Actinomadura and Microtetraspora. System. Appl. Microbiol. 13: 148 160, 1990

13) Athalye, M.; M. Goodfellow, J. Lacey \& R. P. White: Numerical classification of Actinomadura and Nocardiopsis. Int. J. Syst. Bacteriol. 35: 86 98, 1985

14) MeYer, J.: Genus Actinomadura Lechevalier and Lechevalier 1970. In BERGEY's Manual of Systematic Bacteriology. Volume 4. Ed., S. T. Williams et al., pp. $2511 \sim 2526$, Williams \& Wilkins, 1989

15) Goodfellow, M.: Section 30. Maduromycetes. In BerGEY's Manual of Systematic Bacteriology. Volume 4. Ed., S. T. Williams et al., pp. $2509 \sim 2510$, Williams \& Wilkins, 1989

16) Grund, E. \& R. M. Kroppenstedt: Chemotaxonomy and numerical taxonomy of the genus Nocardiopsis Meyer 1976. Int. J. Syst. Bacteriol. 40: 5 11, 1990

17) Shearer, M. C.; P. M. Colman \& C. H. NASH, III: Nocardiopsis mutabilis, a new species of nocardioform bacteria isolated from soil. Int. J. Syst. Bacteriol. 33: 369 374, 1983

18) Takahashi, A.; K. Hotta, N. Saito, M. Morioka, Y. Okami \& H. Umezawa: Production of novel antibiotic, dopsisamine, by a new subspecies of Nocardiopsis mutabilis with multiple antibiotic resistance. J. Antibiotics 39: $175 \sim 183,1986$ 